Original Research Article

\title{
Study on the knowledge of pharmacovigilance among medical students
}

\author{
Lakshmi Deepika Patchva*
}

Department of Pharmacology, Dr. Pinnamaneni Siddhartha Institute of Medical Sciences and Research Foundation, Chinaoutapally, Krishna, Andhra Pradesh, India

Received: 22 November 2017 Revised: 26 April 2018 Accepted: 01 May 2018

\section{*Correspondence to:}

Dr. Lakshmi Deepika Patchva, Email: dreamangles.deepu@ gmail.com

Copyright: (C) the author(s), publisher and licensee Medip Academy. This is an openaccess article distributed under the terms of the Creative Commons Attribution NonCommercial License, which permits unrestricted noncommercial use, distribution, and reproduction in any medium, provided the original work is properly cited.

\begin{abstract}
Background: Pharmacovigilance is the science and activity relating to the detection, assessment, understanding and prevention of adverse effects or any other drug-related problems. The ultimate aim of pharmacovigilance is to ensure safe and rational use of medicines, once they are released for general use in the society. The most important outcome of pharmacovigilance is the prevention of negative consequences of pharmacotherapy. So, the present study primary objective is to assess awareness of pharmacovigilance among medical students and to evaluate the knowledge of pharmacovigilance at Dr. Pinnamaneni Siddhartha Institute of Medical Sciences and Research Foundation, Chinaoutpally (A.P.), a tertiary care teaching hospital.

Methods: A cross-sectional study will be carried out using a pretested questionnaire. The questionnaire will be designed to assess the knowledge regarding pharmacovigilance. The medical students (Final MBBS and Interns) were included in the study during the study period. Only the participants who will give their consent will be included in the study. Results will be calculated by proper statistical analysis.

Results: The current study was conducted in a medical college Dr. PSIMS and RF, which included a total of 180 medical students $75 \%$ final years, $25 \%$ interns. Most of them $(89.8 \%)$ accepted that reporting ADR is necessary and pharmacovigilance should be taught in detail to healthcare professionals.

Conclusions: This study demonstrated that knowledge of pharmacovigilance among medical students is improving gradually, but unfortunately the actual practice of ADR reporting is still deficient among students.
\end{abstract}

Keywords: Adverse drug reactions, Knowledge, Medical students, Pharmacovigilance

\section{INTRODUCTION}

The World Health Organization (WHO) defines Adverse Drug Reaction (ADR) as a "response to a drug which is noxious, unintended, and which occurs at doses normally used in man for the prophylaxis, diagnosis, or therapy of disease or for modification of physiological function". ${ }^{1}$

Adverse drug reactions (ADRs) are one of the leading causes of morbidity and represent a substantial economic burden on healthcare resources. It has been reported that $2.4-6.5 \%$ of the total admissions in the hospitals are due to the adverse reactions, many of which are preventable. The incidence of serious ADRs is $6.7 \%$ in India. $^{2}$

World Health Organization (WHO) defines Pharmacovigilance as "science and activities relating to detection, assessment, understanding and prevention of adverse effects or any other drug related problems". ${ }^{3}$ The ultimate aim of pharmacovigilance is to ensure safe and rational use of medicines, once they are released for general use in the society. The most important outcome of pharmacovigilance is the prevention of negative consequences of pharmacotherapy. To strengthen the pharmacovigolance in India, government has initiated 
pharmacovigilance programme of India (PvPI). Similarly, the Controller General of India (DCGI) and Indian Council of Medical Research (ICMR) have established ADR monitoring centre's in many hospitals in major cities of India. $^{4}$

Pharmacovigilance programs have played a major role in detection of ADRs and banning of several drugs from the market. However, under reporting of ADRs is one of the major problems associated with pharmacovigilance programs. ${ }^{5}$ Monitoring of adverse drug reactions is carried out by various methods, of which voluntary or spontaneous reporting is commonly practiced. Because of variation in drug response, individual prescribing habits, drug regulatory systems, and availability of drugs etc., it has been recommended for every country to set up their own Pharmacovigilance programme. ${ }^{6}$

The major reason behind under reporting of ADRs and Pharmacovigilance programme is due to lack of trained staff and lack of awareness regarding detection, communication and spontaneous monitoring of ADRs among the healthcare professionals (physicians, nurses, pharmacist, and dentists). ${ }^{7,8}$

Pharmacovigilance is still in its infancy in India and there exists very limited knowledge about this discipline. However, The Indian national pharmacovigilance programme lacks continuity due to lack of awareness and inadequate training about drug safety monitoring among healthcare professionals. ${ }^{9}$

Assessment of awareness of pharmacovigilance among the healthcare professionals is very important due to under reporting of adverse drug reactions. Therefore this study was conducted to assess awareness of pharmacovigilance among the medical students and to evaluate the impact of an educational intervention for improving awareness of pharmacovigilance among students. ${ }^{10}$

\section{METHODS}

The present study was carried out after approval from the Institutional Ethics Committee (IEC) in Dr. Pinnamaneni Siddhartha Institute of Medical Sciences and Research Foundation, Chinaoutapally.

This is a study in which a self developed pre-tested questionnaire was designed to assess the knowledge of pharmacovigilance among medical students. Study population consists of 180 students, which include final year medical students and interns. A brief description on the nature of the study and procedure to complete the questionnaire was explained.

The questionnaire which was designed to assess the basic knowledge on pharmacovigilance was distributed among the medical students. Consent form was obtained before starting the study from students.

\section{Inclusion criteria}

Students who are ready to fill the answer for the given questionnaire are included in the study.

\section{Exclusion criteria}

Students who are not interested/willing to answer the questionnaire are excluded from the study.

Filled up forms are collected back from the students and are analyzed for the results. The statistics was done by using MS Excel for obtaining the results. Final data was expressed as frequency and percentages.

\section{RESULTS}

In this study a total of 180 students were assessed regarding their knowledge about pharmacovigilance, of which 27.7 $(n=50)$ were males and $72.2(n=130)$ were females. The mean average age of the respondents was 2023 years.

The demographic details of the healthcare professionals are summarized in Table 1.

Table 1: Demographic details of the healthcare professionals $(n=180)$.

\begin{tabular}{|lll|}
\hline Gender & $\mathbf{N}=\mathbf{1 8 0}$ & Percentage (\%) \\
\hline Male & 50 & 27.7 \\
\hline Female & 130 & 72.2 \\
\hline Study population & & \\
\hline Final years & 135 & 75 \\
\hline Interns & 45 & 25 \\
\hline $\begin{array}{l}\text { Mean age of students } \\
\text { (Years) }\end{array}$ & $20-23$ & \\
\hline
\end{tabular}

In this study, $61.7 \%$ medical students gave correct response regarding the definition of pharmacovigilance. $64.2 \%$ students were aware that the most important purpose of pharmacovigilance is to identify safety of the drug. $93.3 \%$ agreed that ADR reporting is a professional responsibility for them.

Only $44.6 \%$ of students were aware regarding the existence of a Pharmacovigilance Programme in India. $60.8 \%$ were aware that the regulatory body responsible for monitoring ADRs in India is Central Drugs Standard Control Organization (CDSCO). $58.4 \%$ were aware that International Center for ADR monitoring is located in Sweden (Table 2).

In this study, $76.7 \%$ students said they haven't encountered any ADR. And 56.2\% students think the likely cause of the ADRs was drug-drug interactions. $50.5 \%$ Students were saying that they will report ADRs to ADR monitoring committee of the hospital. Some other 
practice related questions and the student's response is given below (Table 3).

Table 2: Knowledge of pharmacovigilance among medical students.

\begin{tabular}{|lll|}
\hline Questions & $\begin{array}{l}\text { Correct } \\
\text { response } \\
(\%)\end{array}$ & $\begin{array}{l}\text { Incorrect } \\
\text { response } \\
(\%)\end{array}$ \\
\hline Define pharmacovigilance & 61.7 & 38.3 \\
\hline $\begin{array}{l}\text { The most important purpose } \\
\text { of pharmacovigilance is }\end{array}$ & 64.2 & 35.8 \\
\hline $\begin{array}{l}\text { Do you think ADR reporting } \\
\text { is professional responsibility? }\end{array}$ & 93.3 & 6.7 \\
\hline $\begin{array}{l}\text { Which of the healthcare } \\
\text { professionals are responsible } \\
\text { for reporting ADRs in a } \\
\text { hospital }\end{array}$ & 54.8 & 45.2 \\
\hline $\begin{array}{l}\text { Are you aware of National } \\
\text { Pharmacovigilance } \\
\text { Programme in India? }\end{array}$ & 44.6 & 55.4 \\
\hline $\begin{array}{l}\text { In India which regulatory } \\
\text { body is responsible for } \\
\text { monitoring ADRs? }\end{array}$ & 60.8 & 39.2 \\
\hline $\begin{array}{l}\text { International center for } \\
\text { adverse drug reaction } \\
\text { monitoring is located in? }\end{array}$ & 58.4 & 41.6 \\
\hline $\begin{array}{l}\text { Where is the Regional } \\
\text { Pharmacovigilance centre? }\end{array}$ & 76.5 & 33.5 \\
\hline
\end{tabular}

Table 3: Practice related questions and percentage of response.

\begin{tabular}{|ll|}
\hline Questions & Percentage (\%) \\
\hline $\begin{array}{l}\text { Do you experience adverse drug } \\
\text { reactions in your patient during } \\
\text { your practice? }\end{array}$ & Yes (21.7) \\
\hline $\begin{array}{l}\text { Do you ever report any adverse } \\
\text { drug reaction (ADR) to the } \\
\text { pharmacovigilance center? }\end{array}$ & Yes (10.3) \\
\hline $\begin{array}{l}\text { Have you seen the ADR reporting } \\
\text { form? }\end{array}$ & Yes (12.5) \\
\hline $\begin{array}{l}\text { Have you ever been trained on } \\
\text { how to report ADR? }\end{array}$ & Yes (15.6) \\
\hline
\end{tabular}

Some more responses given related to pharmacovigilance knowledge are like this: $50.2 \%$ of them think that a serious adverse event in India should be reported to the regulatory body within seven calendar days.

Only $34.7 \%$ were saying that rare ADRs can be identified during $4^{\text {th }}$ clinical trials. $47.8 \%$ of them said that ADR advisory committee is the WHO online database for reporting ADRs. $89.8 \%$ of them are thinking that pharmacovigilance should be taught in detail to the health care professionals and $74.5 \%$ said that "no knowledge of how to report ADR and also where to report" is the discouraging factor for them.

\section{DISCUSSION}

The current study was conducted in a medical college which included a total of 180 medical students i.e. 135 $(75 \%)$ final years, $45(25 \%)$ interns. In many other studies conducted about knowledge and awareness of pharmacovigilance and ADR show lack of knowledge and awareness not only in medical students but also among postgraduates and medical professionals. In study done by Dr. Gupta et al, only $43 \%$ are aware of ADR reporting, where as in this study more than $60 \%$ of students know regarding pharmacovigilance and ADR reporting. ${ }^{8}$

In recent study done by Zaka Un Nisa, 97\% of health professionals can define pharmacovigilance and 34\% can define the ADR. ${ }^{11}$ In another study done by Kutmi M et al, more than $40 \%$ MBBS students think ADR reporting is compulsory and when compared to post graduates regarding witnessed ADR, MBBS students witnessed only $20.5 \% .^{12}$

According to another study done by S Jeya et al, second year MBBs students have adequate knowledge and attitude regarding pharmacovigilance compared to residents and even though nurses have good knowledge about pharmacovigilance they do not have adequate knowledge about reporting ADR. ${ }^{5}$

So, compared to other studies in this study most of the students (89.8\%) accepted that reporting ADR is necessary and pharmacovigilance should be taught in detail to healthcare professionals.

\section{CONCLUSION}

In this study, it was showed that majority of the students had knowledge about pharmacovigilance and understand the need for reporting. In spite of that the reporting rate of ADRs by them is very low. Hence, there was huge gap between the ADR experienced and ADR reported by healthcare professional. Here majority of respondents agreed that reporting of ADR is necessary and it should be made an integral part of the clinical activities in order to improve the patient care.

Our finding strongly suggests that there is a great need to create awareness regarding Pharmacovigilance and to promote the reporting of ADR amongst medical professionals. In conclusion, the results of the present study demonstrate that an educational intervention can increase awareness of pharmacovigilance among the health care professionals and incorporate this gained knowledge of pharmacovigilance into their everyday clinical practice.

It has been advised that the healthcare professionals; especially medical, dental and nursing students should be trained properly on ADR reporting to improve the current scenario in the pharmacovigilance programme of the country. 


\section{ACKNOWLEDGEMENTS}

The authors are grateful to the study participants who voluntarily took part in the study. Authors wish to acknowledge the support provided by the Departments and College, for encouraging research.

Funding: No funding sources Conflict of interest: None declared

Ethical approval: The study was approved by the Institutional Ethics Committee of Dr. PSIMS and RF

\section{REFERENCES}

1. Report of a WHO meeting, WHO technical report, International drug monitoring: The role of national centres, Ser. 1972;498:1-25.

2. Goyal M, Bansal M, Yadav S, Grover V. To Assess the Attitude, Knowledge and Practices of Medical Professionals About Adverse Drug Reactions and Their Reporting in a Teaching Hospital. Ind J of Cli Practic. 2013;24(3):281-4.

3. WHO. The importance of Pharmacovigilance. Geneva. 2002.

4. Patil A, Gurav YA, Thorat MB, Walsangikar SD. Survey of pharmacovigilance awareness among Healthcare professionals. Int J Pharma and Therap, 2014;4(3):31-4.

5. Jeya Ponmari S, Sivaraman M, Aruna T, Subhasree V. Knowledge and awareness of pharmacovigilance among various medical fraternities. Asian $\mathrm{J}$ of Pha and Toxicol. 2015;3(10):45-8.

6. World Health Organisation. Safety of Medicines: A guide to detecting and reporting adverse drug reactions. Geneva. 2002.
7. Desai CK, Iyer G, Panchal J, Shah S, Dikshit RK. An evaluation of knowledge, attitude, and practice of adverse drug reaction reporting among prescribers at a tertiary care hospital. Perspect Clin Res. 2011;2(4):129-36.

8. Gupta SKP, Udupa A. Adverse drug reaction reporting and pharmacovigilance: Knowledge, attitudes and perceptions amongst resident doctors. J Pharm Sci Res. 2011;3:1064-9.

9. Rajesh R, Vidyasagar S, Nandakumar K. Highly active antiretroviral therapy induced adverse drug reactions in Indian human immunodeficiency virus positive patients. Pharmacy Practice 2011 Jan Mar;9(1):48-55.

10. Radhakrishnan R, Danturulu SV, Varma M. An Educational Intervention to assess Knowledge Attitude Practice of pharmacovigilance among Health care professionals in an Indian tertiary care teaching hospital Int J of Pharm Tech Research. 2011;3(2):67892.

11. Nisa ZU, Zafar A, Sher F. Assessment of knowledge, attitude and practice of adverse drug reaction reporting among healthcare professionals in secondary and tertiary hospitals in the capital of Pakistan. Saudi Pharmaceutical Journal. 2018 Feb 6.

12. Kulmi M, Reddy P, Dhakre S, Shinde M, Goyal C. Knowledge, attitude and practices of pharmacovigilance among the postgraduate and undergraduate medical students in a tertiary care hospital in Central India. Int J of Bas \& Cli Pharmac. 2017 Apr 24;6(5):1127-32.

Cite this article as: Patchva LD. Study on the knowledge of pharmacovigilance among medical students. Int J Basic Clin Pharmacol 2018;7:1105-8. 